\title{
Applied translation studies and transdisciplinary action research: Understanding, learning and transforming translation in professional contexts
}

\author{
Gary MASSEY \\ ZHAW Zurich University of Applied Sciences \\ Winterthur, Switzerland
}

\begin{abstract}
Proceeding from accepted shared definitions of applied linguistics that stress its practical, real-world orientation and instrumentality, this article seeks to move the focus from the interdisciplinarity that has been identified as the nexus of translation studies in the past to how its applied branches should systematically engage with an emerging transdisciplinary research paradigm. It argues that the shift can and will be a key factor, challenge and opportunity in the onward development of applied translation studies as it seeks to adequately address the situated realities of professional translation. The article reveals how transdisciplinarity, operationalised as action research, offers a viable framework for investigating, understanding and learning about what translators really do in working contexts and settings, with a view to identifying issues, improving practices, processes and performance, and ultimately transforming the profession for the good of those it employs and serves. In doing so, it considers approaches from cognitive translatology, based largely on a 4EA cognitive paradigm, and translatorial linguistic ethnography, where researchers are gradually but progressively going out into the field to explore and describe the complex socio-cognitive, sociotechnical activity of translation in situ. After presenting a use case from a large-scale research project on translation ergonomics at the author's home institution, the article puts forward a model for transdisciplinary action research in professional settings to guide the necessary transition from interdisciplinarity to transdisciplinarity. Such a model would allow professional processes and practices to be investigated, and the findings productively and transformatively applied, in the situated socio-cognitive and socio-technical contexts of translators' workplaces - within, for, with and by the organisations that employ them.
\end{abstract}

Keywords: applied translation studies, professional translation, interdisciplinarity, transdisciplinarity, transdisciplinary action research, workplace research, cognitive translatology, 4EA cognition

\section{For citation:}

Massey, Gary. 2021. Applied translation studies and transdisciplinary action research: Understanding, learning and transforming translation in professional contexts. Russian Journal of Linguistics 25 (2). 443-461. DOI: https://doi.org/10.22363/2687-0088-2021-25-2-443-461 


\title{
Прикладное переводоведение и трансдисциплинарные исследования: понимание, изучение и трансформация перевода в профессиональных контекстах
}

\author{
Гари МАССИ
}

\author{
Цюрихский университет прикладных наук \\ Винтертур, Швейцария
}

\begin{abstract}
Аннотация
Исходя из общепринятых определений прикладной лингвистики, подчеркивающих ее инструментальность и практическую ориенированность на реальную жизнь, автор настоящей статьи стремится переместить акцент с междисциплинарности, которая в прошлом считалась основой связи прикладной лингвистики с переводоведением, на то, как ее отрасли системно сопряжены с зарождающейся парадигмой трансдисциплинарных исследований. Утверждается, что этот перенос акцента выступает как ключевой фактор, сложность и возможность для поступательного развития прикладного переводоведения, так как он направлен на рассмотрение ситуативных особенностей профессионального перевода. В статье показано, как трансдисциплинарность, ориентированная на исследование деятельности, представляет собой основу для изучения, понимания и узнавания того, что переводчики реально делают в рабочем контексте, с учетом определяющих условий, практик их усовершенствования, процессов и порядка деятельности, а также кардинальной трансформации професии на благо работодателей и заказчиков. Рассматриваются подходы к когнитивному переводоведению, в значительной мере опирающиеся на когнитивную парадигму 4ЕА и переводоведческую лингвоэтнографию, в рамках которых исследователи осваивают научные области, связанные со сложными социокогнитивными и социотехническими видами деятельности на рабочем месте. В статье предлагается модель трансдисциплинарного исследования деятельности в профессионельных условиях с целью необходимого перехода от междисциплинарности к трансдисциалинарности. Такая модель позволила бы исследовать профессиональные процессы и практики, продуктивно применять полученные результаты в ситуативных социокогнитивных и социотехнических контекстах на рабочих местах переводчиков, в организациях, которые являются их работодателями.
\end{abstract}

Keywords: прикладное переводоведение, профессиональный перевод, интердисциплинарность, трансдисииплинарность, трансдисциплинарное исследование деятельности, когнитивное переводоведение, когниция 4ЕA

\section{Для цитирования:}

Massey G. Applied translation studies and transdisciplinary action research: Understanding, learning and transforming translation in professional contexts. Russian Journal of Linguistics. 2021. Vol. 25. № 2. P. 443-461. DOI: https://doi.org/10.22363/2687-0088-2021-25-2-443-461

\section{Introduction}

Brumfit (1995: 27) famously describes applied linguistics as "the theoretical and empirical investigation of real-world problems in which language is a central issue". Focussing on its more practical and empirical aspect, Grabe (2010: 42) defines the field as a "practice-driven discipline that addresses language-based problems in real-world contexts". Another salient definition, by Strevens (2003: 
112), sees applied linguistics as "a technology that makes abstract ideas and research findings accessible and relevant to the real world; it mediates between theory and practice". Strevens thus endows the activities pursued in its name with the instrumental function of bridging a potential or actual theory-practice divide in order to make the study of language and communication relevant. These very broad but complementary perspectives share the notion that applied linguistics, by definition, can and should be practically used to address and help resolve relevant real-world issues that emerge from any locus of linguistic use, interaction or transfer. In short, applied linguistics research is done for practice, about practice and with practice (cf. Cameron et al. 1992: 22).

Rather than representing a discipline in its own right, applied linguistics should be seen as an umbrella term for a diverse collection of activities, disciplines, subdisciplines and areas of interest. That diversity is reflected in the broadening range of publications bearing the applied linguistics epithet. For example, the eminent Routledge series of applied linguistics handbooks ${ }^{1}$ numbers some 45 volumes, covering topics such as language learning and teaching, forensic linguistics, pragmatics, literacy studies, language and identity, language in conflict, language and gender, language and diversity, language and migration, plurilingualism, multilingualism, intercultural communication, communication in workplace and professional settings - and translation studies.

Translation studies itself is a wide-ranging discipline, with only parts of it falling under the purview of applied linguistics. Holmes' (2004) frequently quoted map of the discipline, originally described in 1972 and presented in graphic form by Toury two decades later (1995: 10), makes a clear distinction between its "pure" theoretical and descriptive sub-branches and the "applied" sub-branches of translation training, translation aids and translation criticism. Fifty years on, the distinctions within translation studies are no longer necessarily as clear-cut as they appeared to Holmes. For instance, many of the objects and methodologies of the descriptive translation research being conducted into the products, processes and functions of translation are now feeding directly into applied solutions, such as competence profiling, development and assessment, quality criteria and measurement, workflow management, workplace optimisation and the enhancement of human-computer interactions.

Moreover, it has long been common to regard translation studies not as a discipline but as an interdiscipline (e.g. Snell-Hornby et al. 1994, Chesterman 2002, Sdobnikov 2019), a Phoenician trader travelling among the "settled nations" of other disciplines (Munday 2016: 25) to apply their theories, frameworks, approaches and methods to the complex issues for which it seeks answers. This article attempts to move the focus from the interdisciplinarity that has been identified as the nexus of translation studies in the past to an emerging transdisciplinary research paradigm in its applied branches. It argues that the

${ }^{1}$ See https://www.routledge.com/Routledge-Handbooks-in-Applied-Linguistics/book-series/ RHAL (accessed 28 March 2021). 
shift can and will be a key factor, challenge and opportunity in the onward development of applied translation studies as it tries to adequately address real-world professional translation in workplace and organisational settings. Transdisciplinarity, operationalised as action research, offers a viable framework for investigating, understanding and learning about what translators really do in working contexts, with a view to identifying issues, improving practices, processes and performance, and ultimately transforming the profession for the good of those it employs and serves.

The term transdisciplinarity has numerous and diverse definitions. For instance, Gambier (2019: 358) uses the term "trans-discipline" to designate a possible future evolution of translation studies into "a transversal object of inquiry, common to psychologists, linguists, historians, philosophers, sociologists, economists, etc., shaking up at last the established disciplines". However, this is not the sense in which transdisciplinarity is used here. The current article is based on the broad definition of the Swiss Academies of Arts and Sciences' Network for Transdisciplinary Research ${ }^{2}$. At its core lies Jahn et al.'s definition (2012) proposed in the context of ecological economics:

"Transdisciplinarity is a reflexive research approach that addresses societal problems by means of interdisciplinary collaboration as well as the collaboration between researchers and extra-scientific actors; its aim is to enable mutual learning processes between science and society; integration is the main cognitive challenge of the research process" (Jahn et al. 2012: 4).

The central definition above is supplemented by two further clusters of requirements. The first of these contain criteria relating to the outcome spaces that transdisciplinary research should affect (Mitchel et al. 2015): improving the problem situation, contributing to knowledge about the problem and its flow, and creating mutual transformational learning among researchers and practitioners (i.e. the "extra-scientific actors" mentioned in the above quotation). The second set of requirements concerns the research design, which should have the concomitant capacity to understand the complexity of the issues under investigation, to encompass the diverse perceptions of practitioners and researchers, and to develop descriptive, normative and transformative knowledge (Pohl et al. 2017).

Though some scholars have treated interdisciplinarity and transdisciplinarity as interchangeable terms (Stokols 2006: 68), this expanded definition, which informs the transdisciplinary concept in the present article, takes research a step further than interdisciplinarity. Although distinctions between transdisciplinarity and interdisciplinarity may not always seem clear, "transdisciplinarity generally rejects the separation and distribution of topics and scholarly approaches into disciplinary "silos"" that is inherent in the interdisciplinary concept (Bernstein 2015). This echoes Rosenfeld's (1992) and Stokols (2006) view that, although

${ }^{2}$ https://transdisciplinarity.ch/en/transdisziplinaritat/was-ist-td/ (accessed 28 March 2021). 
interdisciplinarity involves more information sharing and coordination than multidisciplinary projects, the participants "remain anchored in their respective disciplinary models and methodologies" (Stokols 2006: 67). When Munday (2016: 25) attaches the Phoenician trader metaphor to translation studies, he presents a very similar interpretation. The reference harks back to McCarty's (1999) contention that a "true interdiscipline is $[. .$.$] an entity that exists in the interstices$ of the existing fields, dealing with some, many or all of them". It may indeed challenge "the current conventional way of thinking by promoting and responding to new links between different types of knowledge" (Munday 2016: 25), but it still essentially comprises an array of approaches anchored in disciplinary silos. Moreover, this enduring perspective on interdisciplinarity within translation studies remains firmly withing the academic domain - the collaboration that shares and produces knowledge is an exchange between scientific and academic disciplines. Transdisciplinarity, on the other hand, transcends science and academia to actively engage practitioners and other stakeholders in confronting and attempting to resolve real-world issues (Perrin 2012: 5).

The expanded definition of transdisciplinarity sits extremely well with the claims and intentions of applied linguistics that have been noted above - and, by extension, those of the applied branches of translation studies. It also dovetails nicely with the aims and ambitions of action research, which overtly sets out to engage researchers directly with the beneficiaries of their research in pursuit of new knowledge and solutions to practical problems in the real world (cf. Reason and Bradbury 2006: 1). The present article proposes a model combining transdisciplinarity with approaches commonly used in action research to produce investigative work that bridges the gap between scientific knowledge production and societal knowledge demand as "an integral component of innovation and problem-solving strategies in the life-world" (Hoffmann-Riem et al. 2008: 3). Transdisciplinary action research transcends and integrates disciplinary paradigms and embraces participatory collaboration among researchers, professional and social communities, and the organisations embedded in them, in order to identify, address and resolve real-world problems (Hirsch Hadorn et al. 2008: 29, Perrin 2012: 5-7).

The model, however, should not be understood as an attempt to supplant the successful experimental and field research already being done to investigate the situated realities of professional translation. Instead, it is meant to complement it by moving more translation studies research further out into the contexts and settings where professional translation is performed, and by prompting researchers to engage and interact more closely with the stakeholders. A conscious, systematic adoption of transdisciplinary action research, it is argued, can beneficially expand the repertoire of applied translation research at a time when both the profession of translation and translation studies itself are undergoing profound practice-oriented and conceptual transformations (Gambier 2019). 


\section{Applied translation studies: Interdiscipline or transdiscipline?}

Since the beginnings of translation studies and its first systematic mapping by Holmes (2004), the diverse activities and definitions of the applied branches of translation research share with applied linguistics the condition of relevant practical applicability. Holmes original sub-divisions of training, aids and criticism encapsulate three abiding focal points of applied translation research, namely competence (how to translate), resource use (what internal and external support to use) and quality (how to achieve and measure the adequacy of target-text products). To investigate these, researchers should describe and understand not only the practices, processes and products of translation per se, but also the contexts and settings in which translation occurs. Understanding the complex interplay of actors, factors and artefacts is the pre-requisite to identifying, addressing and resolving issues - and thus initiating any necessary transformation.

In a key contribution to research on translation and technical communication in professional contexts, Risku (2010: 103) asks whether embodiment and situatedness really make a difference. On the basis of research performed by herself and others, she concludes that "translation is done not solely by the mind, but by complex systems. These systems include people, their specific social and physical environments and all their cultural artefacts". Risku (2014: 349) later expands on the claim by referring to ethnographic observational research that reveals translators reconfiguring their cognitive space by shifting parts of the cognitive process to bodily movements, interaction with artefacts and the spatial organisation of the workplace. Related arguments have also been put forward by Pym (2011), for whom translation technology has extended and externalised memory, and O'Brien (2012), who considers translation a form of human-computer interaction.

Such claims rest on the substantial foundations of second-generation cognitive science. Clark and Chalmers (1998) were among the first to explicitly postulate that human cognition extends to individuals' physical and social situation, and that cognitive processing comprises the brain's linkage to external environmental elements. It provides the grounding for Hutchins (e.g. 2010) cognitive ecology theory, which models cognition as embodied, embedded, extended and enacted (4E cognition) and moves the attention of cognitive science towards cognitive ecosystems as the assembly of minds, bodies and environmental elements that interact to enable viable action. Wheeler (2005) supplements the 4E model with an affective dimension (4EA cognition).

As Pohl et al. (2017) have already pointed out, research must be properly designed to grasp the sort of complexity that professional translation entails. In translation studies, the bulk of the approaches hitherto adopted have been broadly interdisciplinary in nature. Gambier and Van Doorslaer (2016: 1-4) indicate that studies have comprised four shared basic elements on which other disciplines can help shed light: language, participants, situation and culture. A relevant current example is provided by the sub-discipline of what is increasingly known as "cognitive translatology" (Muñoz Martín 2010a, 2010b, 2016), which is concerned 
with exploring the cognitive underpinnings of how translators work, what enables them to work as they do, with whom they work, where they work and what effects their work has. It has adopted from second-generation cognitive science and complexity theory the concept of translation as a complex situated activity. Cognitive translation research, which draws its core empirical methodology from translation process research (Muñoz Martín 2013: 79), calls for multiple interactions between all four of Gambier and Van Doorslaer's elements, with researchers consistently borrowing theories, approaches, models and methods from linguistics and psycholinguistics, neuroscience, cognitive science, writing and reading research and language-technology research and development ( $\mathrm{O}^{\prime} \mathrm{Brien}$ 2015), to name just a few.

Given the fundamental situatedness of professional translation, it would seem reasonable that research into it should not only be fundamentally interdisciplinary in nature but should also be conducted at least partly in situ. This realisation has been taking hold in recent years, which have witnessed a limited but spreading interest in workplace-based, organisation-oriented translation research. Cognitive translatology, as well as other applied branches of translation studies, have been going out into the field (Risku et al. 2019) to explore translation processes and practices in organisations and at the workplace. In addition to the socio-cognitive approach adopted within the theoretical frameworks of situated and 4EA cognition, Risku et al. (2020: 38-42) have identified sociological and ergonomic layers in their taxonomy of the approaches and theories that currently guide translation-oriented workplace research. The sociological layer includes the still sporadic studies published in the fields of work and industry sociology and organisational studies (e.g. Kuznik 2016, Kuznik \& Verd 2010), more common explorations of actornetwork theory (e.g. Buzelin 2005, 2007, Abdallah 2014) and recent work by Olohan (2017), who applies practice theory to the setting of an in-house translation department. Approaches with an ergonomics orientation, pioneered in theoretical terms by Lavault-Olléon (2011a, 2011b, 2016), have explored the physical, cognitive and organisational dimensions of ergonomics in the translator's workplace (e.g. Ehrensberger-Dow \& Hunziker Heeb 2016, Ehrensberger-Dow \& Massey 2019, Ehrensberger-Dow et al. 2016).

The methods used to elicit and collect translation research data at the workplace can be assigned to four broad categories: compilations of source-text and target-text corpora, including intermediate versions of target texts; ethnographic observational methods, including field notes, audio recordings, video recordings and so on; self-report, comprising surveys, interviews, focus groups, activity logs and similar; and translation process research techniques, themselves derived in large part from psychological and writing research, and normally deployed in mixed-method studies (Ehrensberger-Dow 2014, Ehrensberger-Dow \& Massey 2019, 2020). These include keylogging, screen capture, eye-tracking, think-aloud protocols and retrospective verbal protocols. Data is frequently collected from multiple sources and then triangulated in an effort to increase the validity of the results. To cite some examples, Risku (2016) and Koskinen (2008) deploy 
translatorial linguistic ethnography techniques to study workplace processes and practices in a commercial translation agency in Vienna and an institutional translation unit at the European Commission, respectively. Pedersen (2019) has used similar ethnographic observation methods to explore transcreational processes, spaces and interactions at a marketing implementation agency in London. Ehrensberger-Dow and Hunziker Heeb (2016) and Ehrensberger-Dow et al. (2016) have relied on combinations of ethnographic observational methods, self-report and techniques from translation process research in their investigations of the physical, cognitive and organisational ergonomics of professional translation. These latter studies were conducted in Switzerland and at the European Parliament in Luxembourg, and they were accompanied by international survey data from some 1850 respondents working in almost 50 countries. $^{3}$

It is a truism that no methodology is perfect. Ethnographic observation can be affected by the "white coat" paradox, whereby the phenomena being observed are inadvertently but inevitably influenced by the very presence of an observer or investigator (Ehrensberger-Dow \& Massey 2020). Self-report suffers from decontextualisation (Kuznik \& Verd 2010). Introducing tools for data collection that are unfamiliar to participants may substantially impact on ecological validity. Interoperability issues, ambient factors and infrastructural aspects of the workplace can make it difficult to obtain clean data. Maintaining confidentiality, data and network security, anonymity, consent and organisational reputation should not be underestimated, either. Finally, partner agendas, participant self-selection, restricted access to participants, and the unpredictability of the real-life tasks can also affect research design and outcomes (Ehrensberger-Dow \& Massey 2020).

Nevertheless, the caveats of conducting research in the workplace are outweighed not just by greater ecological validity, but also by its essentially transdisciplinary potential. Research at workplaces and within organisations can create meaningful feedback loops between researchers, practice partners and stakeholders, with the transformational potential of research outcomes that can be directly and immediately applied in the context in which they are generated. The knowledge gains and learning effects promised by transdisciplinary research not only benefit the researchers and their institutions, but also the development of the individuals, groups and organisations that constitute the "communities of practice" (Lave \& Wenger 1991) with and for which the researchers work. In the present author's view, it is therefore the logical way forward for applied translation research as it seeks to fulfil its mission of addressing and resolving relevant real-world issues. Transdisciplinary research is capable of driving individual, community and organisational development in the dynamic, complex systems that the cognitive, sociological and ergonomic approaches described by Risku et al. (2020) seek to describe and understand.

3 The survey report can be downloaded from https://www.zhaw.ch/storage/linguistik/ forschung/uebersetzungswissenschaft/ergotrans-survey-report-en.pdf (accessed 28 March 2021). See also Ehrensberger-Dow et al. (2016). 


\section{Transdisciplinary research: A use case}

In this paragraph, the author presents a use case from his home institution to serve as an illustration. Cognitive and Physical Ergonomics of Translation (ErgoTrans) ${ }^{4}$ was originally conceived as an interdisciplinary project involving experts and perspectives from translation studies, occupational health, usability testing and language technology. It set out to investigate indications of disturbances to the translation process at the workplace, the cognitive and physical ergonomic factors behind them, and how professional translators coped with them. It was run in close cooperation with the language services of Swiss and European institutions, commercial language service providers and freelance translators.

What makes ergonomics a relevant area of interest from the applied linguistics perspective of translation studies? Ergonomics is defined by the International Ergonomics Association (IEA) ${ }^{5}$ as "the scientific discipline concerned with the understanding of interactions among humans and other elements of a system, and the profession that applies theory, principles, data and methods to design in order to optimize human well-being and overall system performance". As such, it takes into account "physical, cognitive, sociotechnical, organizational, environmental and other relevant factors, as well as the complex interactions between the human and other humans, the environment, tools, products, equipment, and technology". There are obvious and immediate connections to be made here with the practice-oriented, interdisciplinary socio-cognitive and ethnographic research discussed above. Indeed, recent work on translation ergonomics in professional and educational settings (Lavault-Olléon 2011b, 2016; van Egdom et al. 2020) has clearly demonstrated how physical, cognitive, social, organisational and environmental factors can and do impact on professional translators' performance, on their efficiency, on their motivation and, crucially, on the adequacy and the quality of the linguistic output for which they are responsible. It is the fundamental intention of transdisciplinary research to applying such knowledge transformatively in order to optimise translators' performance and production.

The ErgoTrans project was designed and carried out by a research team at the ZHAW Zurich University of Applied Sciences between January 2013 and June 2015. The study comprised five separate phases. The first phase was an in-depth analysis of an existing corpus from a precursor study in order to develop hypotheses and refine the instruments for the second phase. Phase two, completed by the mid-2014, consisted of data collection involved video recordings, computer screen recordings, ergonomic assessments and interviews at translators' workplaces. The third phase centred on testing hypotheses generated from the workplace data in a usability lab. Phase four was given over to the aforementioned international survey, run in the second half of 2014. The fifth and final phase of the project involved in-depth interviews with representatives of the different groups of translators

${ }^{4}$ For details about the project and its manifold outputs, see https://www.zhaw.ch/en/ linguistics/institutes-centres/iued-institute-of-translation-and-interpreting/research/cognitive-andphysical-ergonomics-of-translation-ergotrans/.

${ }^{5}$ See https://iea.cc/what-is-ergonomics/. 
studied in the previous phases, the results of which were combined with the findings from the other phases of the study to answer the research questions related to three typical profiles of professional translation: commercial, institutional and freelance translators.

In the course of the project, interactions between, and observations among, researchers, participants and their organisations led to refined or completely new research questions and methods being introduced - the first visible transition of the project from interdisciplinarity to transdisciplinary research. The key research questions that emerged were: What are the indications of disturbances to the translation process at the workplace? Which cognitive and physical ergonomic factors are related to those disturbances? How do professional translators cope with disturbances, and which practices seem to be most successful? Which disturbances seem most difficult to compensate, which cannot be compensated at all, and which might actually have a positive impact on translation performance? Which health complaints might be related to the ergonomics of the translation workplace? In addition, and again as a direct result of the interactive feedback flows between researchers, participants and the institutions involved, a third layer of analysis was introduced to the research design in order to better account for the organisational dimension of ergonomics.

The findings and insights from the project are documented in various academic publications (e.g. Ehrensberger-Dow 2015, 2017, Ehrensberger-Dow \& Hunziker Heeb 2016, Ehrensberger-Dow \& O'Brien 2015, Ehrensberger-Dow et al. 2016, Meidert et al. 2016, Ehrensberger-Dow \& Jääskeläinen 2019, Ehrensberger-Dow \& Massey 2019). However, a less predictable outcome at the inception of the project was that many of the research results would also form the basis for numerous knowledge-transfer publications, blog entries and social-media exchanges for and with professional translators and their associations (e.g. Ehrensberger-Dow \& Massey 2018, O'Brien \& Ehrensberger-Dow 2017, Striebel et al. 2017). Moreover, the research outcomes have been the driving force behind a range of in-service continuing education workshops aimed at commercial, institutional and freelance professionals, as well as a range of learning components distributed across the lead university's BA and MA curricula in applied languages and translation. As a result of findings from the research project, workshops, courses and course units have been designed to sensitise both working professionals and university students to the impact of physical and cognitive ergonomic factors on the efficiency and quality of their work. These have frequently been in conjunction with process-oriented teaching methods, in which participants and students have been encouraged to observe and give feedback to others as they work, and/or to watch and reflect on their own working practices by viewing screen-capture recordings of their activities as they translate. The organisational dimension of ergonomics has also fed into professional development workshops at the European institutions ${ }^{6}$ attended not only by translators but also by their managers.

${ }^{6}$ A recent example is an online training workshop held by the author for the DirectorateGeneral for Translation (DGT) of the European Commission on 23 October 2020 entitled "The 
During the execution of the project itself, the transdisciplinary knowledge generated was already being transferred to players and stakeholders. These had an observable, direct impact on individual participants and institutions from the community of practice. In the second phase of the project, for instance, the occupational health researchers conducted ergonomic assessments at the workplaces of institutional translators working for the European Parliament in Luxembourg and the Swiss Federal Chancellery in Bern. In addition, one concrete outcome of a focus group session conducted at the European Parliament in Luxembourg during the fifth phase of the project, involving participants from both the European Parliament's Directorate-General for Translation (DG TRAD) and the European Commission's Directorate-General for Translation (DGT), was closer cooperation between the DG TRAD and the then ergonomics agent of the DGT. The ErgoTrans project has also led to the Parliament adopting its own initiatives to promote the ergonomics of translators' workplaces and practices. Finally, the DGT's ergonomics agent presented a paper at a conference on translation ergonomics held in 2015 at the University Stendhal Grenoble 3, France (Peters-Geiben 2016) as part of the project's overall dissemination objectives. She was thus able to feed her own institution's experiences, insights and learning outcomes back into the academic community.

To sum up, the project has had a tangible transformative effect on researchers, participants, organisations and practitioners. The project has transferred knowledge back into organisational development and into educational initiatives in both the university and the partner institutions. In an iterative series of interactional loops, it has extended transdisciplinary cooperation, opened up other research questions and avenues, identified more issues and stimulated further solution-finding. Researchers, participants and their organisations have learned, developed, adapted and changed through the various levels of interaction (individual assessments, interviews and exchanges between researchers and participants, focus-group discussions, etc.) in which they were engaged.

\section{Modelling transdisciplinary action research for translation}

The above use case reveals an iterative pattern of knowledge generation and action that can be mapped virtually one-to-one to the classic action research spiral of planning, acting, observing and reflecting, described by its originator, Kurt Lewin (1946: 38), as a "spiral of steps, each of which is composed of a circle of planning, action, and fact-finding about the result of the action". Reflection on research outcomes leads into further cycles of planned, observed, reflectively evaluated action as new issues are addressed (or unresolved ones addressed again), problem situations are improved, knowledge is built and flows between researchers, practitioners and their organisations, and mutual transformational learning takes place among actors - the fundamental conditions of transdisciplinarity defined at

changing face of language mediation: Evolving roles, profiles and competences". See https://digitalcollection.zhaw.ch/handle/11475/20849 (accessed 30 April 2021). 
the start this article (Jahn et al. 20212, Mitchel et al. 2015, Pohl et al. 2017). It is thus wholly legitimate to refer to such research as transdisciplinary action research.

Action research per se has had some isolated proponents in applied translation studies and translator education (e.g. Cravo \& Neves 2007, Hubscher-Davidson 2008, Massey et al. 2015, Massey 2019), all of whom emphasise the added value of the multiple cyclical iterations through which the participants pass in search of solutions to concrete, real-world issues. What makes the difference in the approaches and use case described in this article is the identifiably transdisciplinary framework in which action research is embedded.

Action research within a transdisciplinary framework has already been partially conceptualised by Stokols (2006) for translating psychological research into community problem-solving strategies. For him, its strength lies in the way such an approach and methodology can prioritise "the study of collaborative interactions and outcomes among scholars, community practitioners, multiple organizations and as they occur within local, regional, national, and international contexts" (Stokols 2006: 65). Closer to the concerns of applied linguistics, Perrin (2012) describes very similar aspects of transdisciplinary action research from a project where collaborate academics and media practitioners have collaborated to investigate how the Swiss national TV company and its journalists work, and how measures can be taken so that they can improve their output.

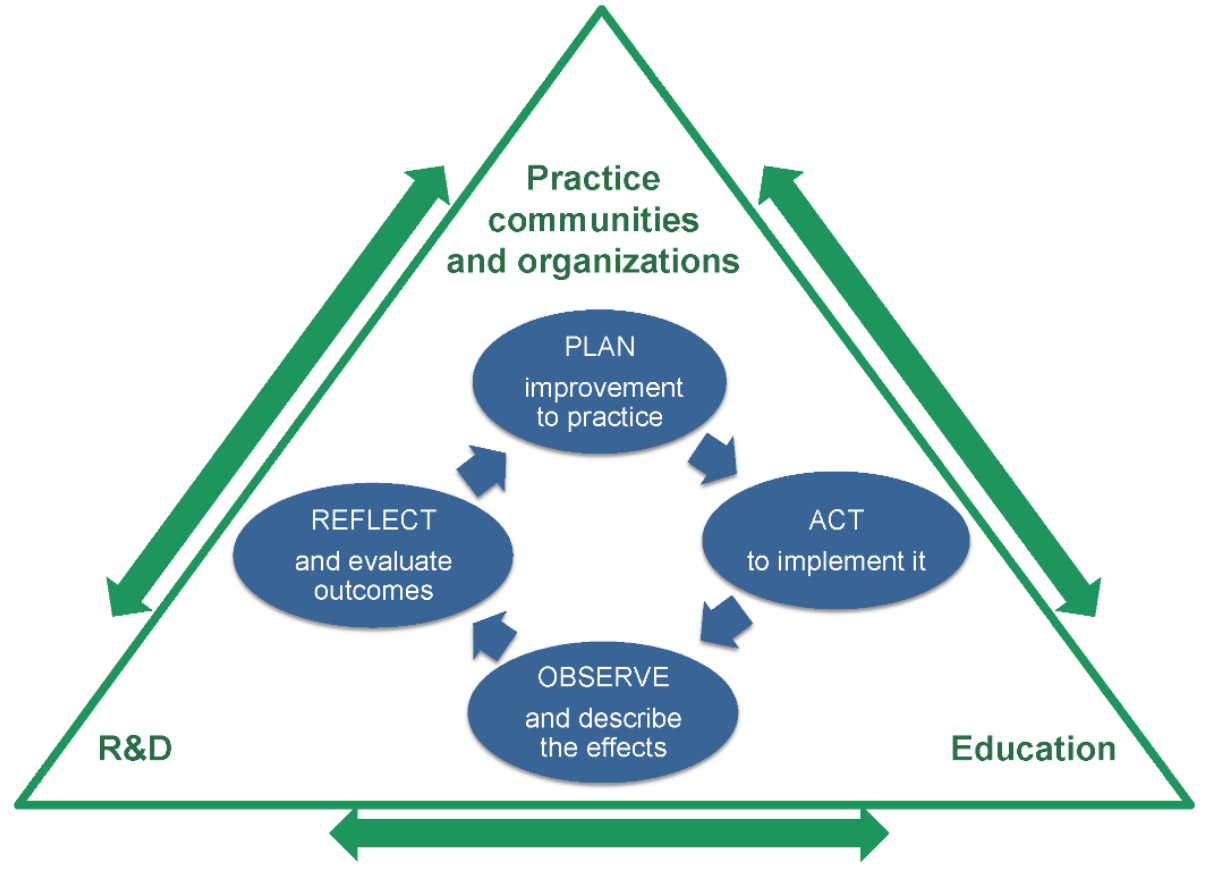

Figure 1. A visual model of transdisciplinary action research applied to translation

Moving into the context of applied translation studies, this article concludes by proposing an integrated model of transdisciplinary action research, rendered visually in Figure 1. It comprises a triangular interactional frame with bidirectional 
vectors running between the three vertices research and development (R\&D), education and, at the apex, communities of practice and their organisations. Within this frame lies the core investigative cycle of the action research process. It is a model that graphically represents the transition that applied translation studies is beginning to make, and must continue making, in order to research and serve the realities of translation in the field. There is a compelling argument for transdisciplinary action research to shape and guide the necessary progression.

\section{Conclusion}

In line with the explicit mission of applied linguistics to address and resolve relevant real-world issues emerging in the various loci of linguistic use, interaction or transfer, the applied branches of the translation studies have sought to meet the condition of relevant practical applicability by exploring issues of competence, resource use and quality. In order to do so, they have had to describe and understand the practices, processes and products of translation within the professional contexts and organisational settings where they are situated and spawned. Interdisciplinary research is readily acknowledged as the pre-requisite for understanding this complex socio-cognitive and socio-technical interplay of actors, factors and artefacts.

However, the present article argues that if insights are to be productively transferred back into the profession and its organisational settings, then an extended action-oriented approach should be added to broaden and enrich the successful range of experimental and field research already being done. It is time to move, consciously and explicitly, from interdisciplinarity to transdisciplinarity. Transdisciplinary action research offers a viable model to drive the transition, allowing professional processes and practices to be investigated, and the findings productively applied, in the situated socio-cognitive and socio-technical contexts of translators' workplaces within the organisations that employ them. The model effectively integrates a core participatory action research cycle within a triangular transdisciplinary frame interconnecting three interactional vertices: translation research and development, translator education, and the communities of practice and organisations in which translation takes place. Shaped and guided by the model, applied translation research can meet the transformational imperative implicit in applied linguistics to properly understand, learn about and enhance the practices, processes, products and settings of translation for the tangible benefit of all the stakeholders in this rapidly evolving profession.

(C) Gary Massey, 2021 (c)creative

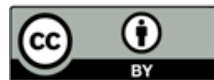

This work is licensed under a Creative Commons Attribution 4.0 International License https://creativecommons.org/licenses/by/4.0/ 


\section{REFERENCES}

Abdallah, Kristiina. 2014. The interface between Bourdieu's habitus and Latour's agency: The work trajectories of two Finnish translators. In Gisella M. Vorderobermeier (ed.), Remapping Habitus in Translation Studies, 111-132. Amsterdam: Rodopi. DOI: https://doi.org/10.1163/9789401210867_009

Bernstein, Jay Hillel. 2015. Transdisciplinarity: A review of its origins, development, and current issues. Journal of Research Practice 11 (1). Article R1. http://jrp.icaap.org/ index.php/jrp/article/view/510/412 (accessed 30 April 2021).

Brumfit, Christopher J. 1995. Teacher professionalism and research. In Guy Cook \& Barbara Seidlhofer (eds.), Principle and Practice in Applied Linguistics, 27-41. Oxford: Oxford University Press.

Buzelin, Hélène. 2005. Unexpected allies: How Latour's network theory could complement Bourdieusian analyses in translation studies. The Translator 11 (2), 193-218. DOI: https://doi.org/10.1080/13556509.2005.10799198

Buzelin, Hélène. 2007. Translations "in the making”. In M. Wolf and A. Fukari (eds.), Constructing a Sociology of Translation, 135-169. Amsterdam: John Benjamins.

Cameron, Deborah, Elizabeth Frazer, Ben Rampton \& Kay Richardson. 1992. Researching Language. Issues of Power and Method. London: Routledge.

Chesterman, Andrew. 2002. On the interdisciplinarity of translation studies. Logos and Language 3 (1). 1-9.

Clark, Andy \& David J. Chalmers. 1998. The extended mind. Analysis 58 (1). 7-19. DOI: https://doi.org/10.1093/analys/58.1.7

Cravo, Ana \& Josélia Neves. 2007. Action research in translation studies. Journal of Specialised Translation 7. 92-107. https://jostrans.org/issue07/art_cravo.php (accessed 28 March 2021).

van Egdom, Gys-Walt, Patrick Cadwell, Hendrik Kockaert \& Winibert Segers (eds.). 2020. Ergonomics. Special Issue of the Interpreter and Translator Trainer 14 (4). https://www.tandfonline.com/toc/ritt20/14/4 (accessed 28 March 2021).

Ehrensberger-Dow, Maureen. 2014. Challenges of translation process research at the workplace. MonTI 7 (2). 355-383. DOI: https://doi.org/10.6035/MonTI.2014.ne1.12

Ehrensberger-Dow, Maureen. 2015. An ergonomic perspective of professional translation. Meta 60 (2). 328-328. DOI: https://doi.org/10.7202/1032879ar

Ehrensberger-Dow, Maureen. 2017. An ergonomic perspective of translation. In John W. Schwieter \& Aline Ferreira (eds.), Handbook of Translation and Cognition, 332-349. Oxford: Wiley-Blackwell. DOI: https://doi.org/10.1002/9781119241485.ch18

Ehrensberger-Dow, Maureen \& Andrea Hunziker Heeb. 2016. Investigating the ergonomics of the technologized translation workplace. In Ricardo Muñoz Martín (ed.), Reembedding Translation Process Research, 69-88, Amsterdam: John Benjamins. DOI: https://doi.org/ 10.1075/btl.128.04ehr

Ehrensberger-Dow, M., Andrea Hunziker Heeb, Gary Massey, Ursula Meidert, Silke Neumann \& Heidrun Becker. 2016. An international survey of the ergonomics of professional translation. ILCEA 27. https://journals.openedition.org/ilcea/4004 (accessed 28 March 2021). DOI: https://doi.org/10.4000/ilcea.4004

Ehrensberger-Dow, Maureen \& Riitta Jääskeläinen. 2019. Ergonomics of translation: Methodological, practical, and educational implications. In Helle V. Damm, Mathilde Nisbeth Brøgger \& Karen Korning Zethsen (eds.), Moving Boundaries in Translation Studies, 132-150. London: Routledge. DOI: https://doi.org/10.4324/9781315121871 
Ehrensberger-Dow, Maureen \& Gary Massey. 2018. Watch and learn: How cutting-edge workplace research can help to improve working conditions for professional linguists. The Linguist 57 (5). 12-13. DOI: https://doi.org/10.21256/zhaw-4036

Ehrensberger-Dow, Maureen \& Gary Massey. 2019. Socio-technical issues in professional translation practice. In Hanna Risku, Regina Rogl \& Jelena Milošević (eds.), Translation Practice in the Field. Current Research on Socio-Cognitive Processes, 105-122. Amsterdam: John Benjamins. DOI: https://doi.org/10.1075/ts.6.1.06ehr

Ehrensberger-Dow, Maureen \& Gary Massey. 2020. Translation workplace-based research. In Minako O'Hagan (ed.), Routledge Handbook of Translation and Technology, 354-369. London: Routledge. DOI: https://doi.org/10.4324/9781315311258

Ehrensberger-Dow, Maureen \& Sharon O'Brien. 2015. Ergonomics of the translation workplace: Potential for cognitive friction. Translation Spaces 4 (1). 98-118. DOI: https://doi.org/10.1075/ts.4.1.05ehr

Gambier, Yves. 2019. Impact of technology on translation and translation studies. Russian Journal of Linguistics 23 (2). 344-361. DOI: https://doi.org/10.22363/2312-9182-201923-2-344-361

Gambier, Yves \& Luc van Doorslaer. 2016. Disciplinary dialogues with translation studies: The background chapter. In Yves Gambier \& Luc van Doorslaer (eds.), Border crossings: Translation Studies and Other Disciplines, 1-21. Amsterdam: John Benjamins. DOI: https://doi.org/10.1075/btl.126.01gam

Grabe, William. 2010. Applied linguistics: A twenty-first-century discipline. In Robert B. Kaplan (ed.), The Oxford Handbook of Applied Linguistics, 34-44. 2nd edn. Oxford: Oxford University Press. DOI: https://doi.org/10.1093/oxfordhb/9780195384253. 013.0002

Hirsch Hadorn, Gertrude, Susette Biber-Klemm, Walter Grossenbacher-Mansuy, Holger Hoffmann-Riem, Dominique Joye, Christian Pohl, Urs Wiesmann \& Elisabeth Zemp. 2008. The emergence of transdisciplinarity as a form of research. Gertrude Hirsch Hadorn, Holger Hoffmann-Riem, Susette Biber-Klemm, Walter Grossenbacher-Mansuy, Donnique Joye, Christian Pohl, Urs Wiesmann \& Elisabeth Zemp (eds.), Handbook of Transdisciplinary Research, 19-39. Berlin: Springer. https://link.springer.com/chapter/ 10.1007/978-1-4020-6699-3_2 (accessed 28 March 2021).

Hoffmann-Riem, Holger, Susette Biber-Klemm, Walter Grossenbacher-Mansuy, Gertrude Hirsch Hadorn, Dominique Joye, Christian Pohl, Urs Wiesmann \& Elisabeth Zemp. 2008. The idea of the handbook. In Gertrude Hirsch Hadorn, Holger Hoffmann-Riem, Susette Biber-Klemm, Walter Grossenbacher-Mansuy, Donnique Joye, Christian Pohl, Urs Wiesmann \& Elisabeth Zemp (eds.), Handbook of Transdisciplinary Research, 3-17. Berlin: Springer. https://link.springer.com/chapter/10.1007/978-1-4020-6699-3_1 (accessed 28 March 2021).

Holmes, James S. 2004. The name and nature of translation studies. In Lawrence Venuti (ed.), The Translation Studies Reader, 180-192. 2nd edn. London: Routledge. (Original work published 1972)

Hubscher-Davidson, Séverine. 2008. A reflection on action research processes in translator training. The Interpreter and Translator Trainer 2 (1). 75-92. DOI: https://doi.org/ 10.1080/1750399X.2008.10798767

Hutchins, Edwin. 2010. Cognitive ecology. Topics in Cognitive Science 2 (4). 705-715. DOI: https://doi.org/10.1111/j.1756-8765.2010.01089.x

Jahn, Thomas, Matthias Bergmann \& Florian Keil. 2012. Transdisciplinarity: Between mainstreaming and marginalization. Ecological Economics 79. 1-10. DOI: https://doi.org/10.1016/j.ecolecon.2012.04.017 
Koskinen, Kaisa. 2008. Translating institutions: An Ethnographic Study of EU Translation. London: Routledge.

Koskinen, Kaisa. 2020. Translatorial linguistic ethnography in organizations. In Sierk Horn, Philippe Lecomte \& Susanne Tietze (eds.), Managing Multilingual Workplaces: Empirical, Methodological and Pedagogic Perspectives, 60-78. London: Routledge. DOI : https://doi.org/10.4324/9780429431128

Kuznik, Anna. 2016. La traduction comme travail: perspectives croisées en ergonomie, sociologie et traductologie [Translation as work: Cross perspectives in ergonomics, sociology and translation studies]. ILCEA 27. https://journals.openedition.org/ilcea/4036 (accessed 28 March 2021). DOI: https://doi.org/10.4000/ilcea.4036

Kuznik, Anna \& Joan Miguel Verd. 2010. Investigating real work situations in translation agencies. Work content and its components. Hermes Journal of Language and Communication in Business 44. 25-43. DOI: https://doi.org/10.7146/hjlcb.v23i44.97263

Lavault-Olléon, Elisabeth. 2011a. L'ergonomie, nouveau paradigme pour la traductologie [Ergonomics as a new paradigm for translation studies]. ILCEA 14. https://journals.openedition.org/ilcea/1078 (accessed 28 March 2021). DOI: https://doi.org/10.4000/ilcea.1078

Lavault-Olléon, Elisabeth (ed.). 2011b. Traduction et ergonomie [Translation and ergonomics]. ILCEA 14. Special Issue. https://journals.openedition.org/ilcea/1031 (accessed 28 March 2021). DOI: https://doi.org/10.4000/ilcea.1031

Lavault-Olléon, Elisabeth. 2016. Traducteurs à l'œuvre: une perspective ergonomique en traductologie appliquée. [Translators at work: An ergonomic perspective on applied translation studies]. ILCEA 27. https://journals.openedition.org/ilcea/4051 (accessed 28 March 2021). DOI: https://doi.org/10.4000/ilcea.4051

Lave, Jean \& Etienne Wenger. 1991. Situated learning: Legitimate peripheral participation. Cambridge: Cambridge University Press. https://doi.org/10.1017/CBO9780511815355

Lewin, Kurt. 1946. Action research and minority problems. Journal of Social Issues 2 (4), 34-46. DOI: https://doi.org/10.1111/j.1540-4560.1946.tb02295.x

Massey, Gary. 2019. The bigger picture: Experiential learning from the classroom to the organization. In Don Kiraly \& Gary Massey (eds.), Towards Authentic Experiential Learning in Translator Education, 2nd edn., 210-231. Newcastle: Cambridge Scholars.

Massey, Gary, Peter Jud \& Maureen Ehrensberger-Dow. 2015. Building competence and bridges: The potential of action research in translator education. In Paulina Pietrzak and Miklaj Deckert (eds.), Constructing Translation Competence, 27-48. Frankfurt am Main: Peter Lang.

McCarty, Willard. (1999). Humanities computing as interdiscipline. http://www.iath.virginia.edu/ hcs/mccarty.html (accessed 30 April 2021).

Meidert, Ursula, Silke Neumann, Maureen Ehrensberger-Dow \& Heidrun Becker. 2016. Physical ergonomics at translators' workplaces: Findings from ergonomic workplace assessments and interviews. ILCEA 27. https://journals.openedition.org/ilcea/3996 (accessed 28 March 2021). DOI: https://doi.org/10.4000/ilcea.3996

Mitchell, Cynthia, Dana Cordell \& Dena Fam. 2015. Beginning at the end: The outcome spaces framework to guide purposive transdisciplinary research. Futures 65. 86-96. DOI: https://doi.org/10.1016/j.futures.2014.10.007

Munday, Jeremy. 2016. Introducing Translation Studies: Theories and Applications. 4th edn. London: Routledge. DOI: https://doi.org/10.4324/9781315691862

Muñoz Martín, Ricardo. 2010a. On paradigms and cognitive translatology. In Gregory M. Shreve \& Erik Angelone (eds.), Translation and Cognition, 169-187. Amsterdam: John Benjamins. DOI: https://doi.org/10.1075/ata.xv.10mun 
Muñoz Martín, Ricardo. 2010b. The way they were: Subject profiling in translation process research. In Inger M. Mees, Fabio Alves \& Susanne Göpferich (eds.), Methodology, Technology and Innovation in Translation Process Research, 87-108. Copenhagen: Samfundslitteratur Press.

Muñoz Martín, Ricardo. 2013.. More than a way with words: The interface between cognitive Iinguistics and cognitive translatology. In A. Rojo \& I. Ibarretxe-Antuñano (eds.), Cognitive Linguistics and Translation, 75-94. Berlin: Mouton de Gruyter. DOI: https://doi.org/10.1515/9783110302943.75

Muñoz Martín, Ricardo. 2016. Reembedding translation process research: An introduction. In Ricardo Muñoz Martín (ed.), Reembedding Translation Process Research, 1-19. Amsterdam: John Benjamins. DOI: https://doi.org/10.1075/btl.128

O'Brien, Sharon. 2012. Translation as human-computer interaction. Translation Spaces 1, 101-122. DOI: https://doi.org/10.1075/ts.1.05obr

O'Brien, Sharon. 2015. The borrowers: Researching the cognitive aspects of translation. In Maureen Ehrensberger-Dow, Susanne Göpferich \& Sharon O’Brien (eds.), Interdisciplinarity in Translation and Interpreting Process Research, 5-17. Amsterdam: John Benjamins. DOI: https://doi.org/10.1075/bct.72.02obr

O’Brien, Sharon \& Maureen Ehrensberger-Dow. 2017. Why ergonomics matters to translators. ATA Chronicle XLVI (1). 12-14.

Olohan, Maeve. 2017. Knowing in translation practice. A practice-theoretical perspective. Translation Spaces 6 (1). 160-181. DOI: https://doi.org/10.1075/ts.6.1.08olo

Pedersen, Daniel. 2019. Managing transcreation projects: An ethnographic study. In Hanna Risku, Regina Rogl \& Jelena Milošević (eds.), Translation Practice in the Field. Current Research on Socio-Cognitive Processes, 105-122. Amsterdam: John Benjamins. DOI: https://doi.org/10.1075/bct.105.03ped

Perrin, Daniel. 2012. Transdisciplinary action research. Bringing together communication and media researchers and practitioners. Journal of Applied Journalism and Media Studies 1 (1). 3-23. DOI: https://doi.org/10.1386/ajms.1.1.3_1

Peters-Geiben, Lucia. 2016. La prévention comportementale et contextuelle: intégrer une approche ergonomique dans la formation des traducteurs [Behavioural and contextual prevention: Integrating an ergonomic approach into the training of translators]. ILCEA 27. https://journals.openedition.org/ilcea/4026 (accessed 28 March 2021). DOI: https://doi.org/10.4000/ilcea.4026

Pohl, Christian, Bernhard Truffer \& Gertrude Hirsch Hadorn. 2017. Addressing wicked problems through transdisciplinary research. In Robert Frodeman (ed.), The Oxford Handbook of Interdisciplinarity, 319-331. 2nd edn. Oxford: Oxford University Press. DOI: https://doi.org/10.1093/oxfordhb/9780198733522.013.26

Pym, Anthony. 2011. What technology does to translating. Translation and Interpreting 3 (1). 1-9. http://www.trans-int.org/index.php/transint/article/viewFile/121/81 (accessed 28 March 2021).

Reason, Peter \& Hilary Bradbury. 2006. The Handbook of Action Research. London: SAGE.

Risku, Hanna. 2010. A cognitive scientific view on technical communication and translation. Do embodiment and situatedness really make a difference? Target 22 (1). 94-111. DOI: https://doi.org/10.1075/target.22.1.06ris

Risku, Hanna 2014. Translation process research as interaction research: From mental to sociocognitive processes. MonTI Special Issue 1. Minding Translation. 331-353. DOI: https://doi.org/10.6035/MonTI.2014.ne1.11

Risku, Hanna. 2016. Translationsmanagement. Interkulturelle Fachkommunikation im Informationszeitalter [Translation management. Intercultural technical communication in the information age]. 3rd edn. Tübingen: Gunther Narr. 
Risku, Hanna. 2017. Ethnographies of translation and situated cognition. In John W. Schwieter and Aline Ferreira (eds.), The Handbook of Translation and Cognition, 290-310. Oxford: Wiley-Blackwell. DOI: https://doi.org/10.1002/9781119241485.ch16

Risku, Hanna, Regina Rogl \& Jelena Milošević. 2019. Introduction. Translation practice in the field: Current research on socio-cognitive processes. In Hanna Risku, Regina Rogl \& Jelena Milošević (eds.), Translation Practice in the Field: Current Research on Socio-Cognitive Processes, 1-24. Amsterdam: John Benjamins. DOI: https://doi.org/ 10.1075/bct.105

Risku, Hanna, Regina Rogl \& Jelena Milošević. 2020. Researching workplaces. In Erik Angelone, Maureen Ehrensberger-Dow \& Gary Massey (eds.), The Bloomsbury Companion to Language Industry Studies, 37-62. London: Bloomsbury Academic. DOI: https://doi.org/10.5040/9781350024960.0007

Rosenfield, Patricia L. 1992. The potential of transdisciplinary research for sustaining and extending linkages between the health and social sciences. Social Science \& Medicine 35 (11). 1343-1357. DOI: https://doi.org/10.1016/0277-9536(92)90038-R

Sdobnikov, Vadim V. 2019. Translation studies today: Old problems and new challenges. Russian Journal of Linguistics 23 (2). 295-327. DOI: https://doi.org/10.22363/23129182-2019-23-2-295-327

Snell-Hornby, Mary, Franz Pöchhacker \& Klaus Kaindl (eds.). 1994. Translation Studies: An Interdiscipline. Amsterdam: John Benjamins.

Stokols, Daniel. 2006. Toward a science of transdisciplinary action research. American Journal of Community Psychology 38 (1). 63-77. DOI: https://doi.org/10.1007/s10464-006-9060-5

Strevens, Peter. 2003. Applied linguistics. In William J. Frawley (ed.), The International Encyclopedia of Linguistics, vol. 1, 112-114. 2nd edn. Oxford: Oxford University Press. DOI: https://doi.org/10.1007/s10464-006-9060-510.1093/acref/9780195139778.001.0001

Striebel, Carola, Maureen Ehrensberger-Dow \& Gary Massey. 2017. Übersetzer-Arbeitsplatz [The translator's workplace]. In Angelika Ottmann (ed.), Best Practices - Übersetzen und Dolmetschen [Best Practices in Translation and Interpreting], 322-334. Berlin: BDÜ Fachverlag.

Wheeler, Michael. 2005. Reconstructing the Cognitive World: The Next Step. Cambridge MA: MIT Press.

\section{Article history:}

Received: 19 November 2020

Accepted: 12 February 2021

\section{История статьи:}

Дата поступления в редакцию: 19 ноября 2020

Дата принятия к печати: 12 февраля 2021

\section{Bionote:}

Gary MASSEY is Director of the Institute of Translation and Interpreting and Deputy Dean of the School of Applied Linguistics at the Zurich University of Applied Sciences (ZHAW), Switzerland. His research interests include translation process and workplace research, translator competence and education, trainer training and the language industry. He has contributed to numerous edited volumes and international journals, and recently co-edited the Bloomsbury Companion to Language Industry Studies (Bloomsbury Academic, 2020). 


\section{Contact information:}

Zurich University of Applied Sciences (ZHAW)

Institute of Translation and Interpreting

Theaterstrasse $15 \mathrm{c}$

CH-8401 Winterthur, Switzerland

e-mail: gary.massey@zhaw.ch

ORCID: 0000-0001-7146-2606

\section{Сведения об авторе:}

Гари МАССИ - директор Института письменного и устного перевода и заместитель декана Института прикладной лингвистики Цюрихского университета прикладной лингвистики (ZHAW), Швейцария. В сферу его научных интересов входят процесс перевода, переводческие и образовательные компетенции, обучение преподавателей и языковая индустрия. Он автор многочисленных публикаций, среди которых главы в коллективных монографиях и статьи в международных журналах. Он также является соредактором издания "Bloomsbury Companion to Language Industry Studies" (Bloomsbury Academic, 2020).

\section{Контактная информация:}

Zurich University of Applied Sciences (ZHAW)

Institute of Translation and Interpreting

Theaterstrasse $15 \mathrm{c}$

CH-8401 Winterthur, Switzerland

e-mail: gary.massey@zhaw.ch

ORCID: 0000-0001-7146-2606 